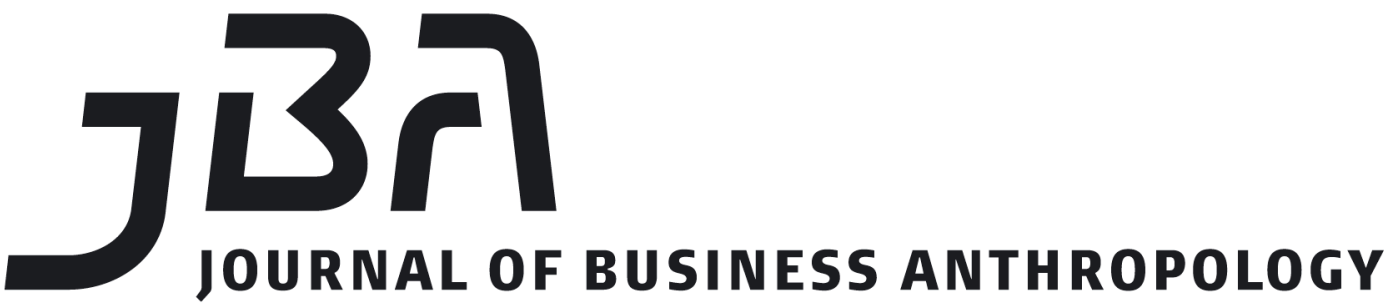

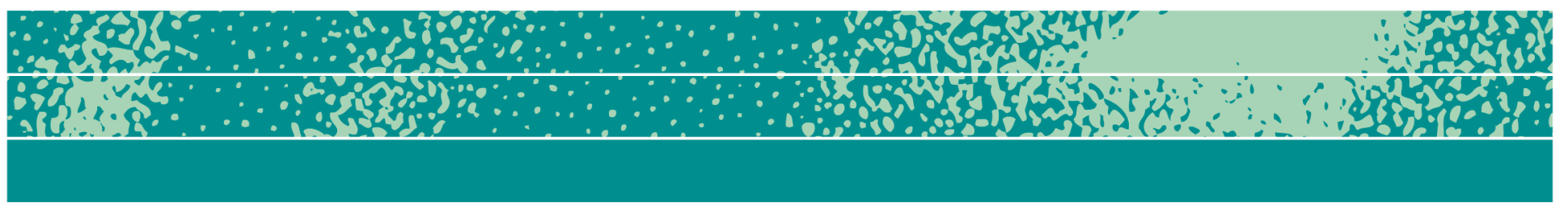

\section{Cheese in Chijnaya: Communal Entrepreneurship in Rural Peru}

Ralph Bolton, Jhuver Aguirre-Torres, Ken C. Erickson

\begin{abstract}
Individual entrepreneurship and social entrepreneurship may be more common both in daily life and in the research literature, but communitybased entrepreneurship also plays an important role in economic development. We present a case study of community entrepreneurship in a rural area of the Andes, where the community of Chijnaya operates a successful cheese production business. Buying milk from its farmer members in the community, the business produces cheeses that are sold in regional urban markets and beyond. This account draws on decades of ethnographic research and collaboration with the community. Here, we discuss the history of the community in general and of the cheese enterprise in particular. The organizational structure of the business is outlined along with a description of the production processes. We end with an analysis of problems faced by the community in moving the enterprise forward toward a more profitable future and a discussion of the relevance of this case to entrepreneurship studies.
\end{abstract}

Page 1 of 26

JBA 8(2): 185-210 Autumn 2019

(C) The Author(s) 2019 ISSN 2245-4217

www.cbs.dk/jba

\section{Key words}

cheese production, ethnography, communal entrepreneurship, Peru, Quechua 


\section{Individual Entrepreneurship on the Peruvian Altiplano}

Andean entrepreneurship has come to the attention of outsiders, both academics and the general public, because of a few salient examples. For instance, the people of Otavalo, Ecuador are famous for selling their artisan goods all over the world, traveling in search of markets (Meisch 2002). Likewise, on the streets of Europe and in some local fairs in the United States, one can find Andean individuals playing traditional huayños on pan flutes and quenas (another traditional type of flute) and selling their music CDs. Within the Andean countries, small-scale entrepreneurship is a pervasive phenomenon with a long tradition (Lidow 2018:163). In Peru, for centuries, members of alpaca herding communities organized annual treks from their homes to distant villages in other ecological zones to exchange their animal products (e.g., skins, fiber, freeze-dried meat) for agricultural products such as corn and potatoes, produced at lower elevations (Flores 1979). These caravans of festively-decorated llamas carrying goods for exchange played an important role in the subsistence economies of communities in an area of vertical ecology where dramatic differences in altitude have a major impact on what people can produce. In the Altiplano, product exchange among people living in different ecological zones is vital for survival (Murra 1972; 2017).

The Altiplano region around the town of Pucará, once a thriving marketing center of earlier civilizations, is famous throughout Peru as home to the "Pucará Bull", a ceramic figure that is a major national icon. The local artisans who produce pottery goods make regular trips to cities all over the country to sell their wares (Flores and Roca 2015). They set up booths at weekly markets and annual fairs where they offer customers traditional clay cookware (rustic pots) as well as a wide array of innovative novelty items, plates, and bowls.

Juliaca, the largest city on the Peruvian Altiplano, is a hotbed of entrepreneurship (See Figure 1). This entrepreneurial activity is manifested most obviously in the merchandising sector where thousands of small shops vie for customers, where street food stands are ubiquitous, and where the drivers of cabs built on top of motorcycles compete for passengers. But the city is also known for its workshops which produce endless quantities of knock-off designer products in addition to high quality original clothing items made of alpaca fiber for sale to tourists and for export. Smuggling of goods from across the border with Bolivia, transported to Juliaca under cover of darkness in truck caravans with armed guards, is another entrepreneurial activity for which the city is known, not to mention the presence of an illicit drug trade (i.e., cocaine). All these activities, both small scale and large, require considerable entrepreneurial talent and sophistication. 


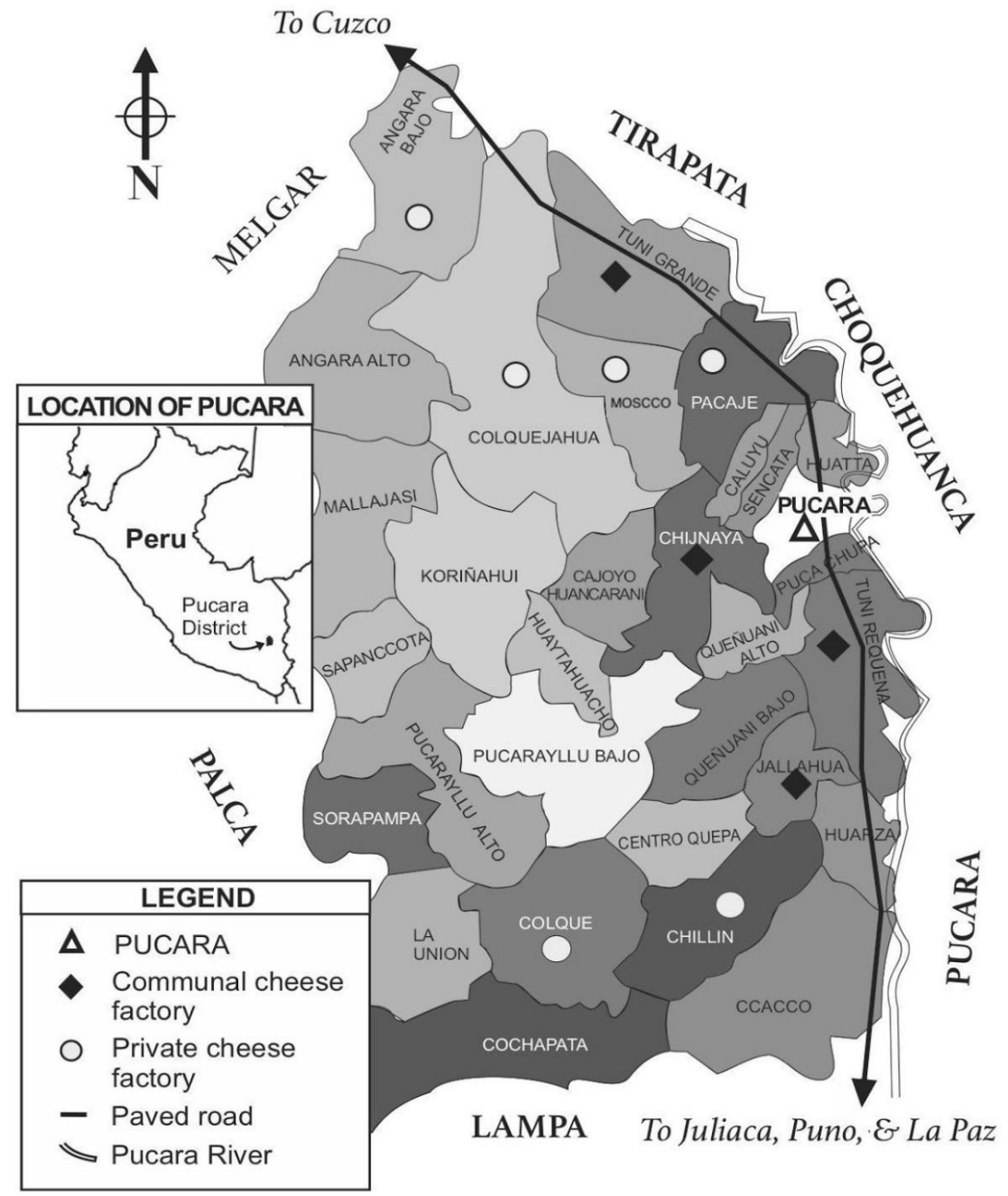

Figure 1. Map of Peru Highlighting the Pucará

The situation on the Altiplano in both rural and urban areas provides an apt example of what Sol Tax (1963) called "penny capitalism". It seems like everyone has some negocio (business), buying, producing, and selling goods and services, even poor subsistence farmers who find that their small plots of land do not provide enough income to maintain a family. Additional sources of income are necessary such as engaging in part-time unskilled labor in the cities or pursuing a trade such as hat making, repairing broken items such as bicycles and sewing machines, weaving, sewing, rope making (Galdo 2018; Galdo and Montalvo 2018; Martínez 2018). Norman Long (1979:123), in his discussion of entrepreneurship in the Mantaro Valley of Peru, writes about this as follows: "An almost ubiquitous feature of underdeveloped economies is the phenomenon of multiple occupations or enterprise, the simultaneous participation of individuals or groups in more than one branch of economic activity."

Finally, it should be noted that people from this region, perhaps 
especially those of Aymara ethnicity, are known in Peru for their industriousness and entrepreneurial skills when they migrate to urban areas such as Arequipa and Lima. Indeed, from the Quechua village of Chijnaya alone, there are numerous emigrant families living in Lima who have created very successful enterprises, among them companies manufacturing high-quality office furniture and leather goods.

\section{Economic and Social Conditions on the Altiplano}

At more than 12,500 feet above sea level, the Altiplano is a vast high plateau in the Central Andes and a harsh environment; natural disasters such as floods, droughts, crop-killing freezes and hailstorms are regular occurrences. This region is shared by Peru and Bolivia. In the 1960s, the Peruvian Altiplano was home to an agrarian population of approximately 700,000 people with $82 \%$ living in rural areas. In 2017 , the population had increased to 1,172,697 with $46 \%$ rural (Vilca 2019). The population is divided almost equally between two major linguistic groups, the Quechua and the Aymara, referred to collectively as Qolla. Overwhelmingly, rural residents are poor farmers in indigenous communities whose livelihood is derived from subsistence agriculture on small plots of land. The principle crops are potatoes, oca (a tuber), quinoa, beans, barley and oats. In lakeside communities, trout fishing was an important part time occupation until overexploitation eliminated it as a significant source of income.

In the past, while most campesinos (a Peruvian term for smallscale agriculturalists) were mostly free and independent, large haciendas occupied vast expanses of the altiplano, especially in areas at slightly higher elevations away from the lake. The proprietors of these haciendas, for the most part, did not live on their estates. Instead, they were absentee landlords residing in Arequipa, Lima or abroad. Hired administrators ran the haciendas which were worked by resident "serfs" known as colonos. The colonos were attached to the hacienda; they exchanged their labor for the right to live on the hacienda, maintain a few animals (e.g., sheep, alpacas, llamas) of their own and cultivate small plots to produce fiber and food for their own families. This system changed with the agrarian reform carried out in 1969 by the left-leaning military government of General Juan Velasco Alvarado. For the most part, haciendas were expropriated and turned into large cooperative enterprises first and eventually into communities in which property was distributed to individual members (Mayer 2009).

Chijnaya is located in the District of Pucará, $60 \mathrm{kms}$ north of the city of Juliaca, and $6.7 \mathrm{kms}$ by dirt road off to the west of the main paved highway that links Puno and Cusco (see Figure 1). While it was quite isolated in the 1960s, that is no longer the case. Truck and bus traffic on the highway that passes through the town of Pucará is now heavy. Pucará 
itself is a poor rural district. It is estimated that $56.6 \%$ of the population by Peruvian standards lives in poverty; indeed, $20.4 \%$ are considered to fall into the category of "extreme poverty." Almost one-fourth of the population of the district is illiterate and $7 \%$ of infants suffer from malnutrition (Aguirre et al. 2016:7-8).

\section{A Brief History of the Community of Chijnaya}

Late in 1962 and the beginning of 1963, heavy rains caused rivers on the Andean Altiplano to overflow and the waters of Lake Titicaca to flood low lying areas in the Department of Puno. The District of Taraco was one of the worst hit areas. The flat Taraco plain extends for several miles from the normal lakeshore at a minimal elevation above the normal water line. This district has one of the densest populations on the Altiplano (Martínez n.d.). Moreover, the Ramis River runs through several communities in the district before entering the lake. In early 1963, that river overflowed its banks and water from the lake rose to levels that flooded the vast Taraco plain destroying homes, livestock, and fields in the middle of the growing season.

Flooding in these areas occurs on a regular basis. The standard response in Peru to recurring disasters is to send some emergency aid in the form of food and clothing, with little or no effort expended to prevent future disasters of a similar kind. When the waters recede, people once more build their homes and lives in the same location. Indeed, another major flood occurred in the mid-1980s in the same communities and with even more destruction. At the time of the 1963 flood, a newly created regional public development agency, the Corporation for the Economic and Social Development of Puno - CORPUNO, became involved. CORPUNO had a Department of Agrarian Reform, but national laws at the time prevented it from engaging in any agrarian reform activities. CORPUNO was established prior to the 1969 agrarian reform. The head of the department, the agronomist Hugo Contreras, saw the flood crisis as an opportunity to initiate a covert pilot agrarian reform program. He proposed to relocate the flood victims to lands on a hacienda at a higher elevation outside the flood zone. Contreras recruited an American Peace Corps volunteer and anthropologist, Ralph Bolton (co-author of this article), who was living in a community adjacent to those severely impacted by the disaster, to help recruit flood victims for what became known as the Proyecto Taraco-Chijnaya (Bolton 2010, 2014). With enormous difficulty, the project finally managed to purchase a hacienda from the holdings of the Catholic church in Puno, thanks to the progressive Bishop of the Church, Julio Gonzáles Ruiz. Recruitment efforts were hampered by political opposition from both the left and right, but a cohort of 72 families was assembled to participate in this experimental relocation project. On September 23, 1963, the male heads of these 
families moved from Taraco to Chijnaya where they began to build a new community.

The Chijnaya hacienda had been leased by the Church to a woman who made minimal use of the property. Only four families of colonos lived on the estate. The men from Taraco arrived and began the arduous task of converting this basically empty terrain into a vibrant community. Over the next two years, they established a school, built homes for all the families, and began to transform the barren landscape into a productive enterprise. In contrast to the dispersed settlement pattern of Taraco, housing in Chijnaya was built in a compact settlement pattern to facilitate the eventual introduction of electrical, water and sewage systems for the community and to permit an optimal usage of the land suitable for cultivation.

From the beginning, it was made clear to prospective participants that the new community they were joining would be run as a cooperative with land, animals and machinery held and operated in common, not individually. This organization of their economic life would involve a drastic cultural change for people who were accustomed to being independent farmers; skepticism was widespread. They would have preferred a project that gave them individual private access to land. The aim, however, was to avoid replicating the minifundia system that dominated in local communities around Lake Titicaca where each successive generation of heirs divides the land into smaller and smaller plots. Over the next two years, the organizational structure for the community was worked out through democratic processes in hundreds of meetings of the members of the community with the participation of Bolton, Contreras, and other CORPUNO personnel. The cooperative was officially recognized and registered with the pertinent government ministry in Lima.

\section{Economic Evolution of Chijnaya}

When the Taraco-Chijnaya Project was conceived, the plan was to establish an agricultural community with a mixed economy involving both animal husbandry (i.e., beef cattle and sheep) and food and feed crop production (of potatoes, quinoa, oca, habas [broad beans], alfalfa, barley and oats) using tractors, plows, balers, fertilizers and chemical pest control. Since the fields and herds were owned by the cooperative, the problems of minifundia would be solved, and modern technology could be applied within the context of a communal enterprise.

This plan worked fine the first season, 1963-1964. The community planted 17 hectares (i.e., 42 acres) in potatoes, one hectare (2.5 acres) in quinoa, and fifty hectares (123.5 acres) of oats and barley, in contrast to the mere three acres Doña María Luisa, the previous operator of the hacienda, had under cultivation. The first year's crops 
were excellent, thanks to the use of improved seeds, insecticides, fertilizers and favorable weather. Indeed, Chijnaya production that year was much better than in surrounding communities. Chijnaya was not as fortunate in subsequent years when severe frosts resulted in major losses of potato crops. It became clear that the climatic conditions in Chijnaya were not suitable for an economy based on the production of tubers and grains such as quinoa.

The next stage in the evolution of the Chijnaya economy involved a reduced focus on agriculture and more on animal husbandry with an emphasis on fattening cattle for meat production. Given the natural pastures on the hacienda and the potential for cultivating alfalfa, barley and oats, agronomists who advised the community urged the switchover to beef cattle with herding done by adult villagers. In this scenario, the cooperative would buy younger skinny animals and fatten them up to sell for slaughter. The acceptance of this recommendation resulted in an added dimension to the economy. The community saw an opportunity to serve in an intermediary role between areas far from the lake and the more densely populated communities along the lake. The cooperative would buy animals in remote communities for resale in communities close to the lake where cattle fattening was being promoted using totora (bulrush) reeds harvested from the shores along the lake as feed for the cattle. The geographical location of Chijnaya in the region between these ecological zones made this intermediary role possible and profitable.

Almost from the beginning of the community, it was recognized that supplemental economic activities would be necessary for the community to thrive. The size of the hacienda was just over 500 hectares, in pasture. This amount of land was not sufficient to sustain a population of approximately 70 families. Moreover, with tasks carried out on a cooperative basis, labor was freed up and could be devoted to other income-generating activities.

In traditional Andean communities, children must contribute their labor to household activities (Bolton and Bolton 2009). In Chijnaya, children were not needed to pasture the animals belonging to the community. Consequently, all children (girls as well as boys) were required to go to school. Thanks to an idea proposed by Robert Purser, a Peace Corps volunteer in the area, the children were encouraged to become artists, embroidering village scenes on handspun woolen cloth (bayeta). Their production of bordados (embroidered goods) was a major success (Bolton 2011). With the help of Remy Alexander, a USAID expert on marketing of crafts, and John Davis, an American artist who was prominent in the art world in Lima at the time, their artwork resulted in an exhibition at the Brooklyn Museum in New York and subsequently a traveling exhibition organized by the Smithsonian Institution. This economic activity brought in $\$ 20,000$ in 1967 . Successful promotion and sales of the embroideries and spinoff products such as embroidered capes 
and handspun alpaca yarn continued into the 1970s (Bolton 2011). With the emergence of the civil unrest in the 1980s created by the Shining Path insurrection (Degregori 2012), the artisans of Chijnaya were no longer able to get their products to Lima for export. Consequently, this source of income fell off dramatically for more than 20 years (Palmer 1992, Starn and Serna 2019), although it made it possible for the community to survive during its startup phase.

Having been copied over the years by people in many other communities on the Altiplano, this artisan activity has become a significant regional industry, especially in terms of producing handicrafts for the tourism sector. After the violence of the Shining Path insurrection ended, the Lake Titicaca region became a major destination for Peruvian and international tourists. Adults in Chijnaya, women and some men, continue to engage in the production of embroideries, selling them to intermediaries. Several local women have achieved national renown for their artistry. They continue to participate in national folk art markets, including the craft fairs sponsored by the Ministry of Culture in Lima. With the sponsorship of The Chijnaya Foundation, for three years (2008 to 2010) these artisans were invited to sell their wares at the largest annual folk art market in the U.S., the prestigious International Folk Art Market in Santa Fe, New Mexico.

As noted above, when Chijnaya was created, its legal structure was that of a production and consumer cooperative, officially recognized by the Peruvian government. Indeed, it was one of the first such cooperatives in the country. For three decades, the community continued to function as a cooperative with the land, livestock and machinery held in common. With extraordinary effort and entrepreneurial spirit, the cooperative managed to acquire two tractors. More significantly, following the 1969 agrarian reform, Chijnaya was able to purchase several neighboring haciendas, more than doubling the size of their initial property.

While the community was organized as a cooperative, individual families were assigned small plots of land for their own private use. However, discontent and divisions in the community led to the dissolution of the cooperative in 1992. Many members of the cooperative felt that economic betterment could be achieved more rapidly by working individually rather than together. The individualist ethos characteristic of Altiplano farmers reasserted itself, and the cooperative began the process of distributing community property among the members of the cooperative. This difficult process was completed in 2002-2003, thereby ending this experiment in cooperative entrepreneurship as far as production was concerned. In retrospect, it is rather amazing that the experiment lasted for as long as it did in view of the highly individualistic nature of Altiplano campesinos and local cultural traditions involving land ownership. There is a romantic misconception, promoted by many 
anthropologists and other intellectuals along with those intent on strengthening ethnic pride, that Andean campesinos are highly cooperative. This stance is indefensible with respect to the daily economy of inhabitants of the Altiplano. There are limited circumstances in which collective action takes place beyond the nuclear or extended family in the economic domain. Competition for land and other resources is often intense, with protracted lawsuits and violence as part of this struggle (Bolton R. and C. Bolton 1975; Bolton 1974, 1979).

Along with structural changes associated with moving from cooperative to private ownership came a new economic strategy involving a different form of animal husbandry. With nongovernmental organization (NGO) and government agency interventions, the community switched from cattle fattening to milk and cheese production-from meat to dairy products.

Various forms of animal husbandry are found on the Altiplano. At the highest elevations, pastoral communities derive their livelihood from herds of alpacas and llamas (Flores 1979). During the latifundia period before the agrarian reform of 1969, most of the land in the region belonged to large estates (haciendas) devoted primarily to raising sheep and alpacas for wool or fleece and meat. However, a few estates had entered the dairy industry, producing high-quality cheeses of various types (gouda, for example) for sale in urban markets.

In most agricultural communities at that time, families raised two or three cows along with 10 to 15 sheep and two to four pigs, primarily for domestic consumption. Traditionally, the cows in indigenous communities were of poor quality, referred to as chuscos. While adapted to the high-altitude environment, these cows were poorly nourished and yielded little milk. This milk was used for the small-scale family production of homemade cheeses to sell, one of the few sources of cash income needed to buy such basic items as sugar, salt, matches, candles, coca and alcohol. A family might make five to 10 small cheeses of the paria type-a soft cheese with a mild taste-to take to market to exchange for other products (Galdo n.d.; Martinez n.d.) In recent decades, however, dairy farming on a small scale has become more prevalent throughout the region due in no small measure to improvements in the genetic stock of dairy cows. Today, in some districts of the Altiplano, including Taraco, the Leche Gloria company, Peru's largest producer of canned milk based in Arequipa, buys milk from the local farmers (Vilca 2019).

\section{A History of the Cheese Enterprise in Chijnaya}

During the period when the original cooperative was dissolved and the communal property distributed to the members of the community, another cooperative was formed with the intention of creating a cheese 
industry in Chijnaya. The history of the cheese business in Chijnaya can be divided into three stages: the "Initial Stage" (1996-2000), the "Revitalization Stage" (2000-2004), and the "Growth Stage" (2004 to the present).

\section{Initial Stage}

The cheese business in Chijnaya began in 1996 with the creation of the Association of Producers of Milk and Dairy Products of Chijnaya (La Asociación de Productores de Leche e Elaboración de Derivados Lácteos, APROLEDL). A legally recognized business entity under Peruvian law, APROLEDL is a communal enterprise whose objective is to provide economic benefits to the people in Chijnaya who own dairy cattle as well as those in neighboring communities such as Ccoriñawi, Moscco and Huancarani-Cajoyo. The stated intent since the beginning has been to develop high-quality dairy products that will be competitive in national and international markets, providing a fair and just income for its members (Aguirre et al. 2016).

The establishment of this business was aided by outside institutions, most notably the Pampa Puno II Project which received European financial backing to promote income-generating programs in the Provinces of Lampa and Melgar. Among the other NGOs and government agencies that assisted the community over the years in this effort were Caritas (2003-2005), FONCODES (1998-2000), PRONOMACH (2004-2006), The Chijnaya Foundation and the Pro-DIA Association (2006-2018), SOLARIS (2011-2014), PRECOMPITE (2015), and TECNOLECHE (2017-2018). Unfortunately, we have been unable to obtain data on how much each of these entities spent on technical assistance and equipment. Such information would be essential to a thorough evaluation of the economic impact of the sums invested in creating this business. We are aware that in some cases funds were spent on expensive equipment that lies idle and that technical advice did not result in the adoption of the recommended business practices.

The first cheese factory, located on the edge of the village, was built in 1996 with funds from the Pampa Puno II Project. Most of the purveyors of milk lived in Chijnaya within 300 meters of the plant. This situation continues to be true in 2019. In the beginning, the plant received approximately 50 liters of milk daily. Accounting documents from this period have not survived. We do know that the first cheese production used milk from the communal herd of cows that still existed at that time. The production process was rudimentary. Large stones were used to press the whey from the curds. The cheeses were not standardized by size or weight since the molds were of different sizes. The cheeses were sold in the weekly market in the nearby town of José Domingo Choquehuanca. The business did not produce a profit. Consequently, the plant closed. 


\section{Revitalization Stage}

The original plant re-opened in 2000, beginning the Revitalization Stage. Various of the government agencies and NGOs mentioned above became involved in motivating the continuation of the cheese making experiment. Community members received training to improve the production procedures. Milk was received in a more orderly manner and notebooks were introduced to keep the records of deliveries, sales and salaries. The plant began to provide accounting reports to the community every three months. When this stage began, only five individuals delivered to the plant milk produced by the cows they owned privately. Most of the milk used in cheese production came from the animals in the Chijnaya herd. Total deliveries in a week were a mere 161 liters. Most people did not sell milk to the plant daily; the amounts delivered varied substantially from one day to the next. By June 2000, six months after the plant re-opened, there were 66 individual providers of milk and an average of 400 liters per day. The majority of the farmers in Chijnaya bought dairy cows, making dairy the most important and dynamic source of income for the community.

Several factors are important in milk production. First, genetically-improved cows must replace the traditional criollo or chusco livestock. Second, adequate feed must be available to support the herd. CARITAS Peru was one of the nonprofit agencies that helped with the second factor by introducing the planting of alfalfa. But to do so, it was necessary to solve the problem of property rights. No individual could plant on community lands. As a result, this need initiated the partitioning of the land from the community to individuals.

\section{Growth Stage}

In 2004, the community became a Centro Poblado Menor, a political subdivision below the level of district. As a result, the cooperative dimensions of the community disappeared for the most part, with the exception of the cheese enterprise and the agricultural equipment belonging to the community. Two groups of residents were formed. One group became the owner of one tractor and some implements, and the second group became owner of the other tractor and its implements.

The first mayor of the Centro Poblado, Pascual Hallasi, solicited support from a government agency, PRONAMACH (National Program for the Management of Hydrographic Basins and Conservation) to improve the infrastructure and equipment of the factory. The remodeled plant was opened in November 2004 in a communal festival with poetry, a meal, and speeches; it was attended by high-ranking officials from the Ministry of Agriculture. At the initiative of Mayor Hallasi, the enterprise was 
incorporated as the "Association of Producers of Milk and the Production of Dairy Products" (APROLEDL - Asociación de Productores de Leche y Elaboración de Derivados Lácteos - Chijnaya). The Association's public registration from 2004 shows is officially registered in Public Registry with a list of members numbering 87 members in 2004 who were by then delivering 800 liters of milk per day.

In 2014, having outgrown the original plant, the community managed to construct a larger plant closer to the center of the village. For a time, the original plant closed after the new plant opened. However, given ongoing expansion in milk production in the community, it became clear fairly soon that the new plant did not have sufficient capacity to handle and process the daily reception of milk. Consequently, the old plant was reopened, and both plants became operational.

The growth in the production of milk can be attributed to several factors. Beginning in 2005, the community began receiving assistance from an American nonprofit organization, The Chijnaya Foundation and subsequently its Peruvian counterpart organization, the Pro-DIA Association. The community presented to the Foundation an ambitious and expensive plan to dramatically raise productivity and incomes. With few resources, the Foundation supported the implementation of select elements in this plan. Using an innovative approach to microfinance with a rotating loan fund of $\$ 12,500$, the farmers were able to acquire the roofing panels, cement, iron rods, and nails needed to construct small adobe sheds to protect the cows from the harsh weather of the Altiplano-rain, cold temperatures, and wind. Within two years, almost all families had constructed sheds in their compounds. These sheds raised milk production significantly; all the farmers repaid the loans with the additional income they received selling the milk (Phillips and Bolton 2008; Bolton, Aguirre and Stromberg 2015).

Additional support from the Foundation involved a loan of $\$ 50,000$ to purchase a John Deere tractor and implements. The lowinterest loan was from a supporter of the Foundation to the community. This equipment allowed the community to increase the amount of land under cultivation substantially, thereby producing feed for the cows. Also, feed availability was increased through the construction of cement feeding troughs, financed through the rotating fund program. Previously the hay and straw were spread before the cows on the ground, resulting in wasted feed from the cows' trampling, urinating and defecating on it.

Another factor contributing to increased milk production was genetic improvements in the herd. The cows in the original herds produced at best four or five liters of milk per day, while the improved cows could produce as much as 18 liters per day. Artificial insemination to improve the genetic stock became widespread with equipment provided initially by the Foundation; later the district authorities and 
several private citizens in Chijnaya initiated artificial insemination enterprises that made artificial insemination readily accessible. Currently, Chijnayans compete with their improved cows at regional fairs, where their animals often win best-in-show.

\section{The Structure of the Enterprise}

The organization since its creation has been participatory. One of the main features of this business initiative is that the people of Chijnaya not only sell milk to the enterprise but they also have the possibility for parttime work in the business. The members of the Board of Directors as well as all the workers are and must be from Chijnaya. The men from Chijnaya received training in cheese making. Board members are elected by the members of the cooperative from the membership in the cooperative, and they serve one year in the office to which they are elected. This procedure follows traditional practices for selecting individuals to serve as political leaders in rural communities of the region. The formal structure of the organization is illustrated in Figure 2.

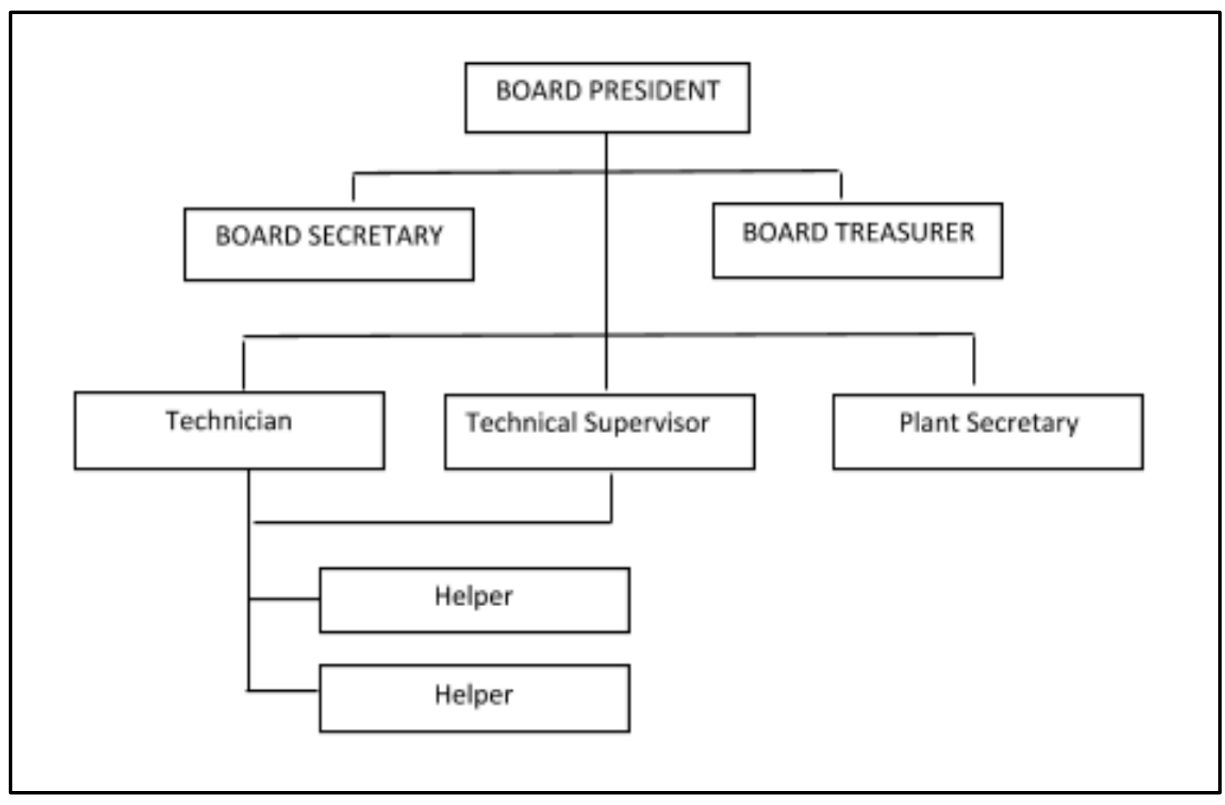

Figure 2. Organizational Structure of the Cheese Enterprise

Members of the Board of Directors (President, Secretary and Treasurer) are elected each year and serve for one year. The operations personnel (technicians, plant secretary and helpers) change each week. They are selected for work by the president. The workers are paid each day. The technicians earn 50 soles ( $\$ 15.65)$, the secretary 48 soles (\$15.00), and the helpers 45 soles $(\$ 14.00)$ each day when they work. The minimum wage in Peru in 2018 was 930 soles monthly (US\$275), about US $\$ 13$ per day. This minimum wage applies only to the formal sector of the Peruvian economy; wages in the informal sector which account for 
between 71 and 73 percent of total employment-where protections are minimal or absent-would be much lower. Both plants are part of APROLEDE and operate with their own employees under one Board of Directors. See Table 1 for the duties of the Board Members and plant personnel.

Table 1. Duties and Responsibilities of Cheese Plant Authorities and Personnel

Board President:

1. Exercises legal, administrative and judicial representation of the business

2. Keeps the community informed about the activities of the business

3. Reports to the community on finances of the business every three months

4. Supervises personnel and oversees adherence to regulations, especially regarding plant hygiene

5. Coordinates with the community the work roles and payment of personnel

6. Orders supplies and materials

7. Supervises plant operations

8. Makes decisions in coordination with the secretary and treasurer

9. Solicits assistance from NGOs and government agencies

Board Secretary:

1. Handles the accounting involving revenue

2. Prepares minutes and accounting reports

3. Coordinates with the treasurer and assists him with tasks as needed

Board Treasurer:

1. In charge of sales, receives the money from the purchasers of the cheese

2. Prepares financial reports for the community, assisted by the president and secretary

3. Pays personnel

4. Purchases supplies and materials in coordination with the president and secretary

5. Keeps the books and checks the daily and monthly financial data, coordinating with the secretary

Technicians:

1. Supervise the operations of the plant, including directing the activities of the helpers

2. Fulfill all of the statutes, norms, regulations and procedures for the operation of the plant

3. Inform the Board of Directors on the operation of the plant, including any problems detected

Helpers: 
1. Maintain the cleanliness of the plant

2. Control the boiling of the milk and the curdling process

3. Carry out any other actions directed by the technicians

\section{Plant Secretary:}

1. Receives the milk from the farmers, registering the amount delivered

2. Helps with the production tasks in the plant

3. Manages the storage facilities

4. Communicates with Board on needed supplies

5. Delivers supplies as needed to the technicians and helpers

6. Hands over the cheese to purchasers

\section{The Production Process: Turning Milk into Cheese}

Each morning around 5:30 a.m., people begin to tend to their cowsfeeding them concentrate in troughs that each family has in their corral area, followed by water around 7:00 a.m. Milking takes place from 8:00 a.m. until 10:00 a.m. Milking is done by hand sitting on a stool and drawing the milk into a bucket. Cows are kept in the compound close to the house at night. Milk is received at the plant until 10:00 a.m. Usually the women in the family do the milking, but men may also perform this task. The milk is poured into aluminum milk cans or plastic buckets with lids which are used to deliver the milk to the factory. These containers are carried by hand, in wheelbarrows, on bicycles or motorcycles, or on carts to one of the factories.

After the milk has been delivered, someone in each family takes its cows to graze on one of the parcels of land belonging to the family, in most cases a nuclear family. Each family has multiple plots of land scattered throughout the territory of the community. This pattern of plot ownership is both traditional and an essential aspect of reducing crop production risks associated with high-altitude climatic conditions. Each family has on average 15 hectares of land for its use. Around noon, the animals are taken to the stream to drink. In the afternoon, the animals are pastured on alfalfa, sometimes contained by wire fences to limit their grazing area. Around 4:00 p.m., the cows are driven home where they may be milked a second time.

The factories open at 8:00 a.m. when the workers on duty arrive at the plant. The workers complete a thorough cleaning prior to receiving the morning's milk. They wash the molds, tanks, tables, presses, pots, buckets, instruments and other cheese-making equipment. Once ready, the secretary begins to accept milk deliveries, writing down in a notebook the amount by weight each person delivers.

The number of individuals who deliver milk each day is approximately 139 (101 from Chijnaya and 38 from neighboring 
settlements - Huancarani, Huaytahuacho, Moscco, Pacaje and Pucará). Currently, each factory receives approximately 1,700 liters of milk daily, but the amount varies somewhat by season. During the rainy season when cattle can graze and receive plenty of nutrition, the amount of milk produced may exceed 2,000 liters per factory. When receiving the milk, the staff does not test for quality, density, total solids or cleanliness of the deliveries. However, instances of mixing water with the milk are not unknown, and plant personnel are on the lookout for any signs that milk being delivered might have been diluted with water.

Beginning around 10:00 a.m. the milk is heated in large tanks. The milk is then curdled using rennet tablets purchased from veterinary supply stores in the city of Juliaca. The curdling process takes about 40 minutes after which the first batch of whey is drained from the tank. Boiled water at a temperature between 45 and 50 degrees Celsius is then poured into the tank of curdling milk. Salt is added to the batter and left to soak for approximately 35 minutes, allowing it to penetrate the curds. At this point the curds are ready for the first pressing which eliminates of most of the salty whey. The presses are hand-operated machines that are used to put pressure on the curds. After placing the curds in the molds (circular wraps measuring $15 \mathrm{~cm}$ in diameter), a second pressing takes place with the curds in the molds. After there is no more whey in the pressed molds, the molds are removed and the Chijnaya logo is pressed onto the cheese. The cheeses are left in the presses for about five hours, and then they are ready. They are taken to the storage room and placed in racks. Each cheese weighs 1200 grams, and 8.8 liters of milk are required to make one cheese.

The factories also receive milk in the late afternoon. Previously, most families milked their cows only in the morning, but increasingly, with higher quality cows that produce more milk, people are doing two milkings per day. Consequently, the cheese production process is repeated beginning at 6:00 p.m. and ending around 8:30 or 9:00 p.m. The workers in the factories put in about 12 hours on the days they work.

Whey is a byproduct of cheesemaking. There are possibilities for utilizing whey to make other products such as ricotta cheese. In Chijnaya, the whey is recycled by the farmers taking buckets of it from the plant to their homes to feed their cows and pigs. But approximately $30 \%$ of the whey (salted) is simply drained into an oxidation pool on the outskirts of the community as waste, which results in contamination of the soil and subsoil in the vicinity of the factories.

Currently, the only type of cheese produced is paria, a soft and mild cheese. No pasteurized or aged cheeses are made. For a time, the first factory produced yoghurt and butter about once a week for sale to the villagers, but those products have been discontinued. 


\section{Economic Data}

The cheese plants buy the milk for 1.3 Peruvian soles per liter, approximately 40 U.S. cents. This price is slightly higher than other cheese factories in the district pay, in part because in Chijnaya, the purveyors deliver the milk to the factory; in other communities the factory collects the milk from the homes of the purveyors. The total cost in milk to produce a cheese is approximately 11.4 soles or $\$ 3.56$ U.S. The cheeses are sold to wholesalers for 13 soles (\$4.06). With approximately 400 cheeses produced daily (with seasonal variations), the daily gross revenue from cheese sales is around $\$ 1,600$ (U.S.).

At present, eight wholesalers purchase all of the production. Two buyers are from Chijnaya; one of them delivers cheeses to Lima and the other sends cheeses to Puerto Maldonado, a city in the jungle region. The other six buyers, from the neighboring town of José Domingo Choquehuanca, sell the cheeses in Lima. These wholesalers have a specific designated day of the week to come to Chijnaya to purchase the cheeses. They sell the cheeses for 18 soles (\$5.62 U.S.). In the markets of La Victoria, a district in Lima, the cheeses are sold to consumers for 23-25 soles each (approx. \$7.50 U.S.). The wholesalers pay in cash for what they buy.

These wholesalers agree to pay a fixed price for the year, providing a buffer to the cooperative against times when product is abundant (and regional prices lower) and protection for the buyer when the dry season's limited milk production can lead to higher prices. These wholesalers are linked through ties of friendship, kinship, and fictive kinship (compadrazgo) to the Chijnaya community. A full accounting of the itinerary of this product and the social relations that surround it as it moves from these wholesale buyers to local, regional, and urban marketplaces will be an important step towards understanding the decisions the cooperative makes (or does not make) regarding their cheese enterprise.

Apparently, when one of the Chijnaya wholesalers was on the board of the cooperative, he offered to go to Lima to find markets so that the cooperative could sell directly to the retailers, bypassing the intermediaries. The coop paid his expenses, but in the end, he set up his own business as an intermediary,

The cheese factory pays the milk producers for the previous week's delivery every Tuesday. As a result, a weekly market has been created in Chijnaya on Tuesdays, with merchants coming from Ayaviri, Juliaca, and José Domingo Choquehuanca to sell their products, knowing that all Chijnayans have money on that day.

The amount that a family earns from milk sales varies considerably, dependent in large measure on the number of cows producing milk and the quality of the cows in the family's herd. Herds 
range in size from three to 15 . The average family has three or four cows producing milk at any one time with a production of at least six liters of milk per cow, or around 21 liters per family. On average, households generate 27.3 soles or $\$ 8.53$ U.S. in cash income. The earnings of the cooperative itself are not substantial; members of the coop do not receive a dividend at the end of the year. Instead, if there is any money left over after all production expenses have been paid, the funds are spent on a variety of activities such as the purchase of uniforms for the local soccer team, prizes for dance competitions, new equipment for both plants, and improvements to the original plant building.

\section{Expert Recommendations for Improving the Business}

In 2011, The Chijnaya Foundation recruited two experts in cheese production to visit the community and analyze the situation of the cheese enterprise. These experts, Poul Hansen and Vicente Álvarez, from Ohio State University and the San Antonio Abad National University of Cusco respectively, spent one week engaged in participant observation on site in the cheese factory. In addition to teaching the Chijnaya personnel how to make different kinds of cheeses and experimenting with flavor modifications to the paria cheeses then in production, they wrote a report with recommendations on how to improve the operation of this business (Alvarez 2011). Their suggestions included the following:

1. Make improvements to the physical plant. Recognizing the lack of space to process the increased production and the need for additional space required for aging cheeses if and when cheeses of other types are produced, the community built a new facility in 2014 and closed the original plant. However, even the new plant was not adequate to handle the increased production, and the original plant was reopened. In celebration of the 50th anniversary of the community, The Chijnaya Foundation gave a grant of $\$ 10,000$ to support the construction of a new municipal government building. The community used part of this money to support the construction of the new cheese plant.

2. Manufacture other kinds of cheeses. The cheese industry on the Altiplano is highly concentrated in the production of only one type of cheese, paria. All the small cheese factories in the region produce this type of cheese. Competition could spell trouble in the future if the market does not expand significantly. It is possible to produce other cheeses such as gouda, mozzarella, and andina which sell for higher prices. By diversifying, the community would not only get ahead of the competition for the market, but the new cheeses would yield more revenue because they are a more upscale product. Even differentiating the paria cheese produced in Chijnaya (e.g., by adding various spices) from those produced in other communities could help. To date, this recommendation by Alvarez and Poulsen has not been implemented. Chijnaya continues to 
produce the same paria cheese, unmodified, despite having been taught how to make new cheeses and to modify their paria cheese. Some other factories in the region have now begun to produce modified flavors of paria cheeses.

Producing other types of cheese means taking on some risk. Introducing a paria cheese with new flavors may require a period of experimentation with the market to create a demand for something new. Andean and gouda cheeses are known and have a market but gearing up to produce those cheeses involves making new investments in infrastructure, changing work habits and implementing new marketing strategies. These changes might entail modifications in the cooperative's relationship with its wholesalers and could subject the producers to price fluctuations that are buffered currently by their pricing agreements.

3. Restructure the management and personnel procedures. Alvarez and Hansen were critical of the system of rotating workers in the cheese plant. They indicated that it was necessary to hire permanent personnel to operate the plant. These workers would receive the necessary periodic training to remain current on cheese production procedures. Moving to a professionally managed operation is hindered. First, the democratic and egalitarian ideal insists on broad participation in the enterprise by all members. Second, everyone in the community needs work, with few alternative options available to them. Hence, despite the recommendation from the team of experts and repeated urgings by members of the ProDIA Association and The Chijnaya Foundation, there does not seem to be any inclination to make the changeover. This resistance may also be due to the high degree of distrust people manifest and the fear of corruption, which may be warranted even with the present management system. For a period recently, the mayor of the community, who was not the official authority in charge of the cheese association, allegedly took charge of operations including the finances; he has been accused of misappropriating funds.

4. Improve production processes. The experts' report contained a series of recommendations regarding changes needed to achieve adequate standards of health and safety. They noted that milking was done in corrals where dust and dirt could contaminate the milk. They recommended milking on cement platforms. They also noted that the containers needed to be more sanitary. And they indicated the need to produce pasteurized products. The purveyors have obtained new containers which are being used to deliver milk from the homestead to the plants. No effort has been made to introduce pasteurization.

5. Change the marketing strategy. By eliminating intermediaries and selling directly to retailers in Lima, the cooperative could gross an extra 5 soles per cheese, or 2,000 soles per day (approximately $\$ 625$ U.S.) or $\$ 2281$ (25 U.S. per year gross). This amount of extra revenue would not 
only pay the salary of an administrator, the costs of shipping, and other expenses associated with direct marketing but would increase the income received by each member by several hundred U.S. dollars per year. This recommendation has not been adopted.

\section{Challenges for the Future: Stagnation or Growth?}

Perhaps the inertia that the community has shown with respect to the recommendations of the experts is due to the fact that they involve a complicated and interrelated mix of changes. Even though it is possible to make some of the changes incrementally, as the Alvarez (2011) report points out, the benefits may not appear until most of the recommendations have been implemented. The payoff is in the future. Quechua campesinos sometimes use a farming analogy to illustrate the concept of delayed gratification, noting that one may plant today, but one does not harvest for many months. A willingness to accept delayed gratification may be missing; on the other hand, participating more broadly in the formal market may present unacceptable risks.

The Chijnaya enterprise is the largest of 18 cheese plants in the District of Pucará. Four of the plants are communally owned and 14 are privately owned; they are dispersed among 14 communities. Cheese plants are classified into three categories depending on the amount of milk processed, the quality of the infrastructure of the business, the types of equipment utilized in cheese production, and the level of hygiene and techniques employed in the manufacture of the cheeses. Only one of these plants achieves an A rating-a private plant in the community of Colquejahua which produces five types of cheese and is at the point of receiving official government certification for quality. The Chijnaya plant receives a $\mathrm{B}$ rating. Most of the remaining plants, many of them quite small, fall into the $\mathrm{C}$ category. It remains to be seen whether privately owned businesses will be more sustainable than the communal enterprises. Perhaps the Colquejahua case is an anomaly, the result of one very progressive and energetic entrepreneur.

\section{Chijnaya and Entrepreneurship}

Research on entrepreneurship cuts across several disciplines and defines entrepreneurship in a variety of ways, depending, in part, on the theoretical orientation of the researchers. Most of the literature favors a positivistic approach, looking for causal relationships among individual entrepreneurs and the opportunities that surround them. Where the literature approaches the topic from a formalist economic perspective, as it most often does, economic maximization is the expected pattern and the assumed goal of entrepreneurship. The focus, in that case, is on the individual rational actor who finds opportunity where others don't, who 
"gets things done," as the economist Schumpeter put it (1947:152).

Nevertheless, the scholars most clearly associated with the development of entrepreneurship as a field of study do not exclude groups of people as analytic foci. Schumpeter (1947:150), perhaps the first economist to explore entrepreneurship in detail, is clear on that point. "Whether we emphasize opportunity or conditions, the responses of individuals or of groups, it is patently true that in capitalist society objective opportunities or conditions act through entrepreneurial activity." Others who study entrepreneurship agree. Shane and Venkataraman's review of entrepreneurship studies suggests groups can indeed be a focus. Though it is in a footnote, they write that "entrepreneurship can be undertaken by a single individual or a set of people who undertake the steps of the process collectively or independently" (Shane and Venkataraman 2000:219). Their efforts, along with Shumpeter's, are considered by Ferreira to be among the most influential in the entrepreneurship literature (Ferreira et al. 2015:8). Although the door has been held open so that collective entrepreneurship can be explored, community entrepreneurship does not arise as topic in Ferreira's systematic literature review.

But some researchers are indeed interested in how whole communities "get things done" in entrepreneurial ways. Peredo and Chrisman (2006) explore how community entrepreneurship might be a helpful approach to learning about Altiplano communities that are venturing at the edges of contemporary capitalism. Johnstone and Lionaise (2004) call many such settings "depleted communities," which parallels the anthropological view of entrepreneurship as a response to a community's marginality. That characterization fits other case studies of entrepreneurship in communities, too (Haugh and Pardy 1999; Traphagan 2017). Counts (1980), reviewing a collaborative effort by anthropologists and economists (Greenfield et al. 1979), rightfully criticized accounts which do not address questions of group versus individual roles in entrepreneurship. A small subgroup of researchers is opening a discussion of indigenous entrepreneurship in which the focus is not on the individual, but on whole communities (Dana 2015; Dana and Anderson 2007; Peredo and Chrisman 2006). These researchers are less interested in causation. They are providing contextually rich descriptions of enterprise development in difficult contexts, including the wider capitalist milieu as one part of the picture of local adaptations to surrounding markets. Such researchers are certainly in the minority, however, as the bulk of the research on entrepreneurship is done in socalled Western settings. The work to date rarely includes community struggles-against the kind of environmental and social pressures faced by communities like this one on the Altiplano.

When Peredo and McLean write about community entrepreneurship they note that "analyzing the economic life of these 
societies in terms of standard classical and neoclassical economic assumptions distorts and misrepresents the economic realities of those societies" (2013:604). It should be no surprise that both individual profit motive and collective forms of exchange co-exist in the same place. Both money-making and socially-embedded wholesaler relationships coexist in Chijnaya community. Dana (2010) points out a similar pattern among Sámi herders, whose herding work is hardly profitable but ties them to their traditions while they engage in other, more remunerative enterprise. Those who study Andean communities expect multiple patterns to be present at once. In this way, the realities of Chijnayan enterprise reported here offer a counterpoint to much of the individuallyand economic-rationality-focused entrepreneurial research. The cheese enterprise in Chijnaya fits with the emerging discussions of community entrepreneurship in the scholarly literature. The story in Chijnaya, though, is hardly over.

\section{Final Thought}

Will the community's entrepreneurial spirit kick in and lead to further development of the enterprise, or will complacency, disunion and conflict result in stagnation and possibly failure? We may not know the answer for several years. Chijnaya has a history of resilience, of being able to adapt to a changing environment. However, structural changes in the political and social organization of the community, from being a cooperative, in which all participated to becoming a Centro Poblado, with less control over its citizens and whose very structure embodies a more individualistic ethos, may spell trouble for this experiment in community entrepreneurship.

\section{References}

Aguirre, J., J. Araoz, A. Candia and D. Quiroz. 2016. Evaluación financiera del proyecto - mejora de la planta procesadora de quesos APROLEDL Chijnaya, Puno, Perú. Report submitted as part of the requirements for the diploma program on project management, ESAN University, Lima, Peru.

Álvarez, V. 2011. Planta Quesera APROLEDL-Chijnaya: Procesamiento y Manufactura de Queso Paria. Report prepared for The Chijnaya Foundation, Palm Springs, California.

Bolton, C. and R. Bolton. 2009. El trabajo de niños en la sociedad andina, In La vida familiar en comunidades andinas: Estudios antropológicos en la sierra sur del Perú. Ralph Bolton. Pp. 243-260. Lima, Peru: Editorial Horizonte. [Original, 1982. El trabajo de niños en la sociedad andina, 
Paper presented in the Congreso de Investigación acerca de la Mujer en la Región Andina. Lima, Perú.]

Bolton, R., J. Aguirre and A. Stromberg. 2015. Micropréstamos en el Perú rural: el modelo Chijnaya de fondos rotativos, In Antropología Aplicada en el Perú: Estudios de Casos. J. Ávila and R. Bolton, eds. Pp. 55-88. Lima, Peru: Editorial Horizonte.

Bolton, R. 1974. El abusivo y el humilde: participación diferencial en conflictos entre los Qolla, Allpanchis Phuturinqa 6:42-78.

Bolton, R. 1979. Differential Aggressiveness and Litigiousness: Social Support and Social Status Hypotheses, Aggressive Behavior 5:233-255. https://doi.org/10.1002/1098-2337(1979)5:3<233::AIDAB2480050302>3.0.C0;2-0

Bolton, R. 2010. Chijnaya: The Birth and Evolution of an Andean Community, Memories and Reflections of an Applied Anthropologist, In Vicos and Beyond: A Half Century of Applying Anthropology in Peru. T. Greaves, R. Bolton, and F. Zapata, eds. Pp. 215-263. Lanham, MD: AltaMira Press.

Bolton, R. 2011. Achachis y Bordados: Storytelling Embroideries from Chijnaya, Peru, Lecture at the opening of an exhibition at the Museums of the University of Richmond.

https://www.youtube.com/watch?v=tMcsnY5i5lI, Accessed July 20, 2019.

Bolton, R. and C. Bolton. 1975. Conflictos en la familia andina. Foreword by J. A. Flores-Ochoa Translated into Spanish by J. A. Flores-Ochoa and Y. D. N. Vizcarra. Cuzco, Peru: Centro de Estudios Andinos.

Dana, L. P. 2010. The Social Role of Entrepreneurship Strategies among Sámi Family SMEs. Rencontres (Conference papers, Montpellier Business School) https://www.kmuhsg.ch/rencontres/Renc2010/Topics_2010/B/Rencont res_2010_Topic_B_Dana_f.pdf Accessed August 10, 2019.

Dana, L. P. 2015. Indigenous Entrepreneurship: An Emerging Field of Research, International Journal of Business and Globalisation 14(2):158169. https://doi.org/10.1504/IJBG.2015.067433

Dana, L. P. and R. B. Anderson, eds. 2007. International Handbook of Research on Indigenous Entrepreneurship. Cheltenham, UK: Edward Elgar. https://doi.org/10.4337/9781781952641

Degregori, C. I. 2012. How Difficult It Is to Be God: Shining Path's Politics of War in Peru, 1980-1999. Madison, WI: University of Wisconsin Press.

Dunnell, T. 2018. The Current Minimum Wage in Peru in US Dollars and Soles. The New Peruvian. May 31.

http://www.newperuvian.com/current-minimum-wage-in-peru-in-usdollars-and-soles/ Accessed September 20, 2019. 
Ferreira, M.P., N. R. Reis, and R. Miranda. 2015. Thirty Years of Entrepreneurship Research Published in Top Journals: Analysis of Citations, Co-citations and Themes, Journal of Global Entrepreneurship Research 5(1):2-22. https://doi.org/10.1186/s40497-015-0035-6

Flores O. J. 1979. Pastoralists of the Andes. Foreword and translation by R. Bolton. Philadelphia, PA: ISHI Publications.

Flores O. J. and D. Roca. 2015. El torito de Pukara: cerámica tradicional de Ch'eqa Pupuja, In La cultura expresiva puneña: Religión, arte y folklore. Tomo II, Serie Etnografía Clásica en el Altiplano Peruano. R. Bolton, ed. Pp. 271-325. Lima, Peru: Editorial Horizonte.

Galdo P., R. and A. Montalvo. n.d. Dos comunidades altiplánicas: Camicachi y Chinchera, In Comunidades y parcialidades puneñas: Antes de la reform agraria. Tomo III, Serie Etnografía Clásica en el Altiplano Peruano. R. Bolton, ed. Lima, Peru: Editorial Horizonte. [In press]

Galdo P. R. n.d. El indígena y el mestizo de Vilquechico, In Comunidades y parcialidades puneñas: Antes de la reforma agraria. Tomo III, Serie Etnografía Clásica en el Altiplano Peruano. R. Bolton, ed. Lima, Peru: Editorial Horizonte. [In press]

Greaves, T., R. Bolton, and F. Zapata, eds. 2010. Vicos and Beyond: A Half Century of Applying Anthropology in Peru. Lanham, MD: AltaMira Press.

Greenberg, S. M., A. Strickon and R. T. Aubey, eds. 1979. Entrepreneurs in Cultural Context. Santa Fe, NM: School of Advanced Research.

Haugh, H.M. and Pardy, W. 1999. Community Entrepreneurship in North East Scotland, International Journal of Entrepreneurial Behavior \& Research 5(4):163-172, https://doi.org/10.1108/13552559910293119

Johnstone, H. and D. Lionais. 2004. Depleted Communities and Community Business Entrepreneurship: Revaluing Space through Place, Entrepreneurship \& Regional Development 16(3):217-233. https://doi.org/10.1080/0898562042000197117 Lidow, D. 2018. Building on Bedrock. New York, NY: Diversion Books. Long, N. 1979. Multiple Enterprise in the Central Highlands of Peru, In Entrepreneurs in Cultural Context. S. Greenfield, A. Strickon and R. Aubey, eds. Pp. 123-158. Santa Fe, NM: School of Advanced Research.

Martínez, H. n.d. El indígena y el mestizo de Taraco. In Comunidades y parcialidades puneñas: Antes de la reforma agrarian, Tomo III, Serie Etnografía Clásica en el Altiplano Peruano. R. Bolton, ed. Lima, Peru: Editorial Horizonte. [In press]

Mayer, E. 2009. Ugly Stories of the Peruvian Agrarian Reform. Durham, NC: Duke University Press. https://doi.org/10.1215/9780822390718

Meisch, L. A. 2002. Andean Entrepreneurs: Otavalo Merchants and Musicians in the Global Arena. Austin, TX: University of Texas Press. 
Murra, J. 1972. El control vertical de un máximo de pisos ecológicos en la economía de las sociedades Andinas. In Ortíz de Zuñiga, ed. Visita de la Provincia de León de Huánaco en 1562. Tomo 2. Huánaco, Peru: Universidad Hermilio Valdizán, 429-476.

Murra, J. 2017. Reciprocity and Redistribution in Andean Civilizations. Chicago, IL: University of Chicago Press/HAU.

Palmer, D. S., ed. 1992. The Shining Path of Peru: A Study of Sendero Luminoso. New York, NY: Palgrave Macmillan.

Peredo, A.M. and J. J. Chrisman. 2006. Toward a Theory of Communitybased Enterprise, Academy of Management Review 31(2):309-328. https://doi.org/10.5465/amr.2006.20208683

Peredo, A.M. and M. McLean. 2013. Indigenous Development and the Cultural Captivity of Entrepreneurship, Business \& Society 52(4), pp.592620. https://doi.org/10.1177/0007650309356201

Phillips, B. and R. Bolton. 2008. Happy Cows and Milk Production: The Economic Impact of a Micro-Loan Program in Chijnaya, Peru, Paper presented at the annual meeting of the Society for Applied Anthropology, 27 March, Memphis, Tennessee.

Schumpeter, J. A., 1947. The Creative Response in Economic History, The Journal of Economic History 7(2), pp.149-159. https://doi.org/10.1017/S0022050700054279

Shane, S. and S. Venkataraman. 2000. The Promise of Entrepreneurship as a Field of Research, Academy of Management Review 25(1), pp.217-226. https://doi.org/10.5465/amr.2000.2791611

Starn, O. and M. La Serna. 2019. The Shining Path: Love, Madness, and Revolution in the Andes. New York, NY: W.W. Norton \& Company.

Vilca, P., ed. 2019. Puno en el siglo XXI: Desarrollo, ambiente y comunidades. Lima, Peru: Asociación Servicios Educativos Rurales. 
Ralph Bolton, Ph.D., is Emeritus Professor of Anthropology at Pomona College where he taught for 44 years. A specialist on Peruvian highland cultures, he has published, as an author or editor, more than 20 books on diverse aspects of life in the Andes. His most recent volumes include Vicos and Beyond: A Half Century of Applying Anthropology in Peru (co-edited with T. Greaves and F. Zapata), Susto, coca y los efectos de la altura en la cultura andina, and Cuys, camiones y cuentos en los Andes. Bolton is the founder and president of The Chijnaya Foundation, a nonprofit dedicated to promoting health, education and economic development in Altiplano communities. His awards include the Franz Boas Award for Exemplary Service to Anthropology (American Anthropological Association), the Sargent Shriver Award for Distinguished Humanitarian Service (National Peace Corps Association), and Doctor Honoris Causa degrees from the National University of the Altiplano, Puno and the San Cristóbal National University of Huamanga, Ayacucho.

Jhuver Aguirre-Torres received his bachelor's degree in anthropology from the National University of the Altiplano in Puno, Peru. He has engaged in graduate certification programs in various fields including project management at the San Agustín National University of Arequipa, the Pontifical Catholic University of Peru in Lima, and ESAN, the Peruvian business school. He has co-authored publications on microfinance and development projects on the Altiplano. He is currently the Director of Operations of the Pro-DIA Association, a Peruvian nonprofit working to reduce extreme poverty in the Andes. He is responsible for coordinating the activities of a network of 24 community organizations engaged in projects involving rural tourism, the production of handspun alpaca yarn, agricultural innovation using rotating funds, and ceramics production. In addition, he coordinates a program that provides 50 scholarships annually to enable youths from needy families to go to college.

Ken C. Erickson, PhD., is a practicing anthropologist with over 30 years of experience conducting public policy and business research for State and Federal Governments, business associations, and international businesses. He has published on refugees, beefpacking workers, ethnographic methods and design research for differentlyabled airplane travelers. Erickson's recent ethnographic work has included multi-site team ethnography for NASA, an international retailer's store design efforts, and fieldwork with artisanal wood crafters in Western Hunan, China. Erickson's current research focuses on small and non-employer businesses. Erickson is a clinical faculty member in the International Business department at the Darla Moore School of Business at the University of South Carolina and a board member at Yokoji Zen Mountain Center in Mountain Center, California. 